\title{
STRIKE ACTION AND WORKING-CLASS POLITICS ON CLYDESIDE 1914-1919*
}

\begin{abstract}
"Mr McClure said that in going round Govan recently he had found a spirit he had never expected to find and that spirit was the spirit that was lightheartedly prepared to advocate tomorrow the revolution they had had in Russia. [. . .] Mr McClure was asked why the people of Russia had not crushed Bolshevism [. . . ]. The pandemonium made it impossible to follow the proceedings." McClure was the unsuccessful Coalition candidate for Govan in 1918, Govan Press, 13 December 1918.
\end{abstract}

"Sir Thomas Munro who visited Glasgow in January after careful enquiry reported that $121 / 2 \%$ advance was not, in his opinion, an active factor in the situation, and that unrest was due to the activities of a pacifist and revolutionary section of the men industriously working on the general dissatisfaction which existed. This element has been prominent in the Clyde area more than in any other district during the whole course of the war." W.S. Churchill, 8 February 1918 (Public Record Office, London PRO) ADM 116 1608; WC GT 3597).

SUMMARY: The record of strike activity on Clydeside is used to explore the interaction between workplace organisation and political attitudes in working-class communities, focussing in particular upon the shipyard labour force in the years immediately preceding the 1919 General Strike. The findings are used to question research by Iain McLean which minimised the political significance of industrial militancy during the period of the Red Clyde and that by Alastair Reid, which argued that the main consequences of wartime industrial experience were to strengthen social democratic perspectives. It is suggested that a limited but significant radicalisation did occur and that this was related to the specific labour relations practices of employers in the west of Scotland and the structural weakness of Clydeside's economy.

* This article is based on a paper presented at the Colloquium on Working Class Movements and their Revolutionary Potential at the end of World War 1, Graz, June 1989. I would like to thank Richard Price, Chris Wrigley and James Cronin, among other participants, for their comments, and, subsequently, Joseph Melling and Alan McKinlay. 


\section{Introduction}

During the First World War Clydeside's industries employed 70,000 shipyards workers, 90,000 coal miners, another 40,000 workers in iron and steel and 170,000 in other branches of engineering, metal working and chemicals. ${ }^{1}$ These workers, 370,000 in total, represented $35 \%$ of the labour force - more than double the average proportion for similar occupations in Great Britain as a whole. In addition, Clydeside had a large number of workers in the docks, railways and road transport, many of them employed in relatively big concerns, and a significant factory population in textiles and food production. The size of this massive proletariat, one of the most concentrated in Europe, gave rise to expectations that, of all regions within the country, Clydeside might sooner or later become Britain's Petrograd.

These expectations remained unfulfilled. Britain emerged victorious from the war. There was no breakdown in the supply of food or everyday necessities. The Lloyd George government gave every appearance of monolithic cohesion and had the almost undivided support of all sections of property. Indeed, in the 1918 election it seemed to have the backing of a majority of workers.

But the lack of any revolutionary crisis in Britain, or even of a prerevolutionary situation, does not mean that the wartime activity of Clydeside's workforce is without interest. It is significant that the Clyde, like other areas of Britain, did not produce a sustained wave of anti-war industrial protest during the war itself. Despite the existence of a massive factory proletariat and a war which gave it an unprecedentedly strong bargaining power, there was no equivalent to the anti-war strikes which took place in Germany and Austria in the spring of 1918. This lack of response raises all the issues relating to the apparent quiescence of British workers. At the same time it was Clydeside, of all places in Britain, which appears to have witnessed the highest levels of politicised industrial unrest. The pro-Soviet attitudes of young shipyard workers cited earlier found a still more dramatic sequel the following month in the general strike of January 1919. To this extent Clydeside's somewhat unusual experience also presents us with opportunities for probing the nature of Britain's apparent exceptionalism.

To begin with, however, in order to get a sharper focus on what did or did not happen, we need to clear a certain amount of historical undergrowth.

${ }^{1}$ The inclusion of Ayr as well as Dumbarton, Glasgow, Renfrew and Lanarks is because the boilermaker's Clyde District included the Ayrshire ports. The use of the 1921 census probably results in an underestimate of the numbers employed during the war. 


\section{The Red Clyde and revisionist legends}

Iain McLean published his Legend of Red Clydeside in 1983. This sought to demonstrate, quite effectively according to most reviewers, that the Red Clyde was a myth, powerful as such, but no more than that.

Essentially McLean's argument is that the existence of the Red Clyde, as a geographical area with socialist class politics, is a case of mistaken identity. A mass Labour vote did develop between 1919 and 1922. But it was Labourist, not socialist. Its leader was the Catholic municipal reformer, John Wheatley, and it was developed through local community campaigning on issues of housing supply and rent levels. It had little or no connection with the wartime politics of the shop stewards' movement and the handful of Marxist militants who eventually formed the Communist Party. On the contrary, McLean argues that the Marxist socialist element on Clydeside was always basically isolated, socially and politically, and only rose to prominence during the war because of its ability to use, and coexist with, conservative elements among skilled craft workers. The wartime unrest in the factories of Clydeside was, for McLean, essentially defensive: to maintain craft differentials, to defend existing privileges and in particular to exclude women from male preserves. Marxist socialists in the leadership of the Clyde Workers' Committee could call strikes on these issues, but lost support whenever they sought to go further. In fact, claims McLean, it was only because the government did, in 1916, take on and defeat the conservative craft elite within the Clydeside workforce that the way was opened for a broader, less industrial leadership within the local Labour Movement which appealed, on a community basis, to the needs of women, the semiskilled, and the casually employed. But in the process the Marxist left lost whatever base it had.

According to Iain McLean, the myth of the Red Clyde developed because subsequent historians, like Hinton and Middlemas, gave too much credence to the self-serving accounts of wartime shop stewards. Hinton, in particular, sought to use the main organisation of the wartime shop stewards' movement, the Clyde Workers' Committee, to provide revolutionary credentials for an industrial rank-and-file movement in Britain. Against this McLean shows that the Clyde Workers' Committee (CWC) was split between the socialist idealogues like John Maclean and the more pragmatic shop stewards leaders who knew the limits of their power. The support for the CWC was restricted to only one sector of industry, engineering munitions, where the threat of dilution and female labour was strongest. Once the government took the offensive on the political issues, the support for the CWC disappeared very quickly and the official leadership of the engineers union (ASE) re-established its control. Indeed, says McLean, the ASE fought hard and effectively to secure a fair settlement of workshop 
grievances. By May 1916 the Clyde Workers' Committee was effectively broken. It played no real part in mobilising opposition to conscription in 1917 or in 1918 and for the two final years of the war the Clyde was markedly less active than the other munitions centres of Sheffield and Manchester. Finally, when it comes to examining the rise of electoral support for the Labour Party, the key period was after the war. Labour did very badly in the December 1918 election in Glasgow and only won one seat out of fifteen. The development of electoral support came in the three years up to 1922 and was geographically correlated with the worst areas of overcrowding and rent pressures. It was not, McLean concludes, industrially derived. Nor was it, in any broader sense, class conscious. ${ }^{2}$

McLean's reappraisal matches, and is complemented by, Alastair Reid's study of the workers in Clydeside's shipyards. Reid also contests the notion of a Red Clyde - although from another direction. He argues that the Marxist Labour historians writing after the last war, particularly Hobsbawm, left us with a stereotyped and unfactual account of the social and political attitudes of skilled workers. He identifies the problem in terms of what he calls an existentialist view of class consciousness. Either people are seen as totally ideologically committed to a Marxist view of society - or, if they are not, they are in some way corrupted and contaminated by the ideas of the existing order. For the late 19th century this involves the promotion of the Leninist concept of a Labour Aristocracy bribed with the profits of Britain's empire. Reid, examining the actual character of the shipbuilding workforce, argues that this has little base in reality.

First of all, he claims that it is not easy to define any culturally or economically differentiated stratum within the shipbuilding workforce. Inside individual trades, such as riveters or platers, there were wide variations in earnings. Some of the higher paid tradesmen had to contend with higher levels of unemployment. Others, such as riveters, only received higher pay as a result of intensely hard and often dangerous work. More important, there is little indication that these skilled workers acted ideologically as agents of capital within the Clydeside Labour Movement. They reveal a diversity of ideological and cultural perspectives and to the extent that they did have common attitudes, these sprang from their position as trade unionists: a determination to defend wages and conditions, a pride in their organisation and a steady commitment to the improvement of social welfare, housing and education. They were not doctrinal socialists or anything like it. But they nonetheless provided the human material from

${ }^{2}$ Iain McLean, The Legend of Red Clydeside (Edinburgh, 1983). The main texts criticised by McLean are James Hinton, The First Shop Stewards' Movement (London, 1973), and R. K. Middlemas, The Clydesiders (London, 1965). 
which Labour politics were built in Britain. Borrowing some of the ideas of Stedman Jones, Reid argues that class politics are in reality alliance politics. Class politics occur when a political organisation is able to provide a common framework for a whole variety of disparate cultures among working people, all of which have their own separate legitimacy. The achievement of Labour Party on Clydeside was to create an organisation that could articulate this. Its strength was precisely its tolerance of diversity and not the assertion of some totalitarian uniformity.

During the war Reid claims that it was this "practical socialism" which emerged as the victor. Looking at strikes in Clydeside shipbuilding between 1915 and 1917 (but curiously not 1918 and 1919) he finds no evidence of a rank-and-file revolt. The district delegates and local officials of the Boilermakers Society kept the confidence of their members and effectively defended their rights against notably incompetent and authoritarian managements. In doing so they found welcome allies among the Board of Trade and Ministry of Munitions officials, and it was this experience which played a considerable part in clinching new political orientations after war. The post-war realignment, claims Reid, was not corporativist. It was not a response to some crisis of control because there was none. On the contrary, it derived from a practical alliance, forged during the war, between tradeunion leaders and middle-class progressives who had sought to establish a more efficient and rational organisation of production. The new perspectives were straightforwardly reformist, and motivated by common concerns for welfare and social progress.

Again, therefore, we are left without the Red Clyde. Clydeside's Labour identity was reformist and constitutional. The talk of a Scottish Petrograd was no more than a flight of fancy. Continuities, especially of the pre-war Labourist tradition, were far more important than any activity by rank-andfile socialists during the war. ${ }^{3}$

\section{Industrial conflict on the Clyde 1914-1919}

In fact this revisionist reconstruction bears surprisingly little relationship to any historical reality. Quite remarkably, neither author sees fit to examine the central phenomenon of the Red Clyde, that is, the overall scale, sequence and character of its strike activity. Their concern with industrial politics is essentially negative: to demonstrate factual errors in existing accounts and this is particularly so in McLean's case. Because Hinton

${ }^{3}$ Alastair Reid, "The Division of Labour in the British Shipbuilding Industry, 18801920 with special reference to Clydeside", (Ph.D. thesis, Cambridge, 1980) (especially chapter 7), and "Dilution, Trade Unionism and the State in Britain During the First World War", in S. Tolliday and J. Zeitlin (eds), Shopfloor Bargaining and the State (Cambridge, 1985), pp. 45-74. 
concentrated his attention on the munitions strikes of 1915 and early 1916 , and on workers' responses to what Hinton saw as the growth of the "Servile State", this is where McLean also concentrates. He successfully demonstrates that the suppression of Forward, and the deportation of the shop stewards in 1916, was considerably more complex than shown by either Hinton or Brotherstone; that Gallacher named the wrong establishments as striking over rents in 1915; that the Clyde Workers' Committee had a narrow base, was limited to half a dozen of the major munitions factories, and that its influence was at an end by May 1916. But we look in vain for any information on the overall pattern of industrial conflict in the west of Scotland during the years 1914 to 1919. Attention is focussed almost exclusively on the events of 1915 and 1916.

The data on strike activity shows just how dangerous this concentration is. Figure 1 makes it clear that the climax of industrial unrest on the Clyde occurred not in 1915 but at the end of the war and was principally located in shipbuilding and heavy industry. ${ }^{4}$ Figure 1 also supplies some measure of the exceptionality of the Clyde. No other place in Britain witnessed industrial action of anything like the general strike proportions seen in the west of Scotland in January 1919. The strikes of 1915 , which certainly caused the government some concern, are dwarfed by the $1 \frac{1 / 4}{4}$ million days lost in January 1919 - or even by the 300,000 days lost at the beginning of 1918 .

Naturally enough, McLean and Reid have little reason to consider why the west of Scotland might be so exceptional, and this leads to the second major flaw in their accounts. Although they are ostensibly analysing regional politics, both remain geographically non-specific. No attempt is made to place the west of Scotland within the very uneven political economy of Britain's regional development. The argument here is that this uneven development is central to any understanding of Clydeside's politics. It was the material weakness of Scottish capital, together with its particular cultural traditions, which inhibited the development of those social and cultural relationships which sustained - relatively speaking at least - social stability elsewhere. The Redness of the Clyde, as against the Mersey or the Tyne, had a quite different pedigree which did not result so much from the breakdown of existing pre-war structures of collective bargaining as from their very weak and truncated existence and the wider lack of civic cultures which gave organised labour a recognised and autonomous place. It was precisely because Clydeside had not developed a labour aristocracy in the classic sense. Next, however, before considering why Clydeside might be so exceptional, we need to establish the magnitude of the action.

4 Board of Trade Labour Gazette, monthly 1914 to 1919 . Some checks have been made using Public Record Office MUN 5/5 and MUN 1/15 [hereafter, PRO]. 


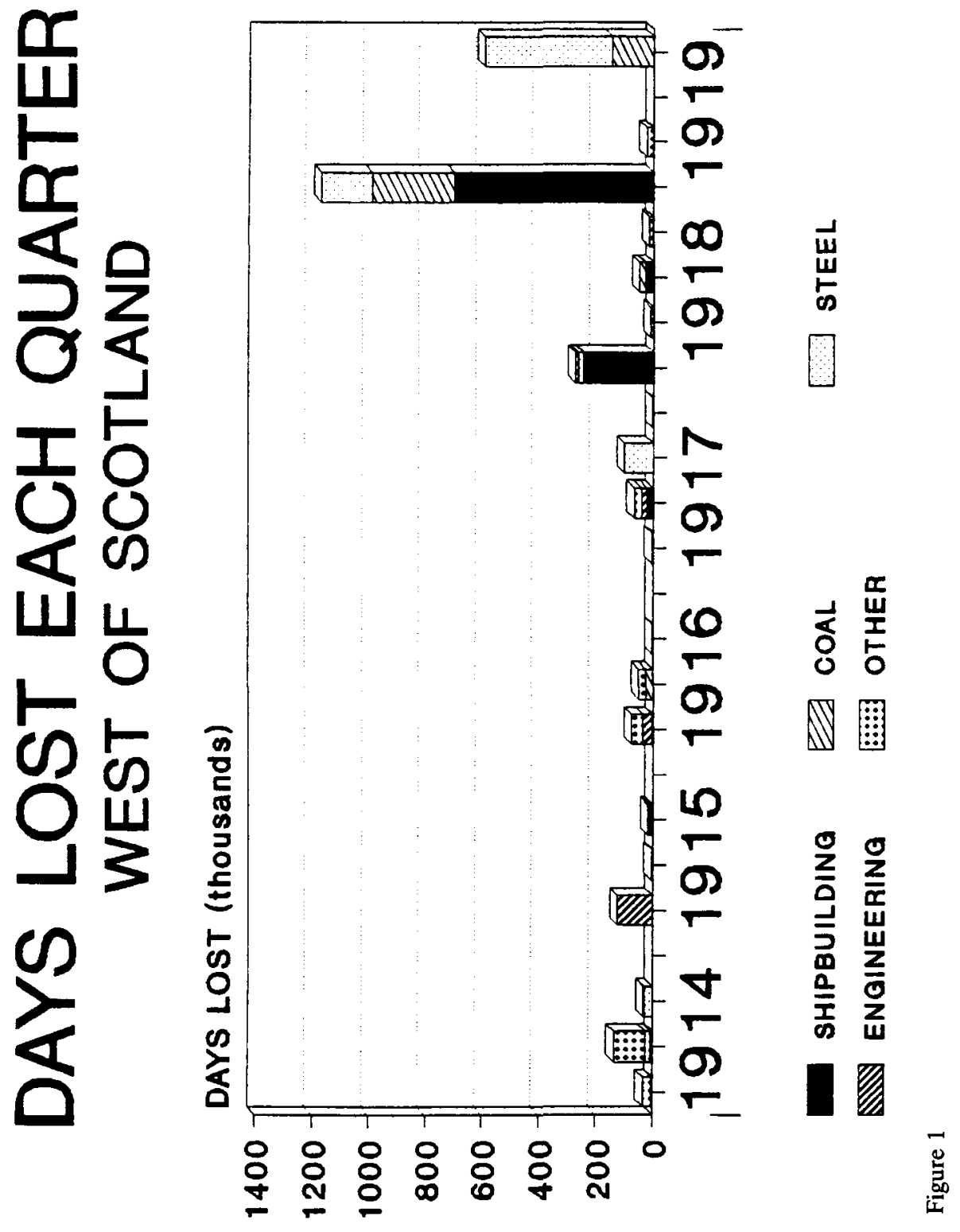


The information in Figure 1 is drawn from the Board of Trade's monthly listing of principal disputes. These include all strikes lasting more than 24 hours and involving directly or indirectly more than ten persons. The days lost include both those directly striking and those laid off as a result. Geographically, the material covers the industrial belt of west central Scotland, and includes the counties of Ayr, Dumbarton, Lanarks and Renfrew. Although wartime censorship restricted press reportage of strikes and hence limits the usefulness of other sources, the listings appear to be complete and are not different from those on file in the Ministry of Munitions. They do, however, by definition omit the major one day stoppages in November 1915 (by shipyard workers over rents) and on May Day 1918 and 1919 (upwards of 50,000 workers on each occasion). They also exclude the large number of stoppages lasting less than a day which were particularly frequent in the shipyards. Yet the picture that emerges is one that is very different from what any reader of McLean would expect.

As we have noted, the strikes by munitions workers in 1915 and 1916 comprise only a relatively small fragment of the illegal wartime strikes, and in terms of magnitude, the strikes of 1919, and above all January-February 1919, far exceed anything that came before. These post-war strikes were concentrated in particular among the workers in large-scale industry, specifically, shipbuilding, coal and steel. Yet it is also noteworthy that between 1915 and 1917 almost as many days were lost among other grades of workers, and that these strikes were often about workers rights in the struggle to develop unionisation. In the literature these sometimes quite remarkable strikes seem to have been completely forgotten. Just to mention a few. In July 1915 2,000 explosives workers struck for four days to stop the victimisation of clerks who had joined a union. In March-April 1916 3,000 printing workers struck work for over a month over the employment of scab labour. In May they struck work again to gain a guarantee that their employers would never again attempt a lockout. In May and June 1916 there was a spate of small strikes among women workers in flax, laundry works and clothing factories for wage increases. These are mentioned not out of piety but to draw attention to dates and categories of workers. April, May, June 1916 was after the deportation of the Clyde Workers' Committee leaders and at a time when McLean gives us to understand that industrial militancy had collapsed. Yet this did not stop workers, including many hitherto un-unionised women workers, taking action that put them directly in conflict with the state.

This is a point of some importance when we relate it to the other elements of McLean's thesis: that the real base of the Labour Party's rise to power was in the politics of the community and through the support of the housewife as the payer of rent. A glance at these statistics of industrial conflict should remind us that many of these women had entered employ- 
ment during the war and had then had to fight for their own trade-union rights. This experience of workplace direct action was readily transferred to the community, and McLean's attempt to pose one sphere of activity against the other betrays the weakness of his grasp of what was happening in wartime industrial relations. Typically, strike action and industrial militancy was not the prerogative of a small group of conservatively-inclined craftsmen. On the contrary, wartime conditions opened up the possibility of collective action to a population which had been previously excluded from it - and in circumstances that demanded at least some ideological reorientation about the nature of state power and its relation to capital.

Of still greater significance, however, is the exponential rise of strike action during the last phase of the war and into 1919, and its concentration in the shipbuilding and, to lesser extent, coal and steel industries. The strikes of early 1918 were about wages - although they occurred in the context of anti-war feeling among at least a section of the shipbuilding workforce. This sentiment was directly demonstrated by the widespread strike action on May Day 1918. The January strike of 1919 was different in kind. This was because it involved all sections of the workforce and was on the general issue of hours and unemployment. It demanded a forty-hour week in order to provide employment for discharged soldiers and did so with the explicit objective of preventing the re-development of an unemployed reserve. It was therefore a political strike which directly sought to affect the balance of power between capital and labour and place pressure on the government. We will look at the details later, but it is important to note that its defeat did not of itself break the militancy of the workforce. There was a further massive one-day political strike on May Day 1919, and some coalminers again struck work for shorter hours in the autumn of 1919.

None of this fits easily into the revisionist analysis of either Iain McLean or Alastair Reid. Against Reid the upsurge of strike action in the shipyards in 1918 and 1919 shows unofficial leaders in control and leading the biggest rank-and-file revolt anywhere in Britain. Class issues were explicitly posed as such. A clash of ideological positions occurred, and for the moment those on the Left won. For McLean these strike statistics would seem to present an even bigger challenge. The crux of his thesis is that the change in political attitudes came after the 1918 election and therefore cannot be linked to wartime industrial unrest. Yet it is clear that the culmination of political strike action on Clydeside also occurred after the 1918 election. Indeed, more than this. Its geographical location points a finger directly at another aspect of McLean's narrowed focus. When setting out his research plan, McLean notes that he takes the Red Clyde to be Glasgow and that his analysis of election results will be limited to the city boundaries. He claims, without presenting any evidence, that this is really what people meant at the time and that there was little political or industrial contact between workers 
in Glasgow and those in Paisley, Motherwell or Greenock. A moment's contemplation of the location of large-scale heavy industry will reveal the consequences of this redefinition. Steel, coal and shipbuilding communities were either on the periphery of Glasgow or altogether outside. And so, in almost exact congruence, were those constituencies where Marxist socialist candidates scored their major successes. Figure 2 shows the percentage votes achieved by selected Labour candidates where it is possible to make a direct comparison from 1918 to 1923 . Two things become immediately obvious. First, there was significant electoral support for candidates supporting Communist or pro-Third International positions, and that this was largely concentrated in shipbuilding or steel and coal areas. Secondly, comparing those candidates taking pro- and anti-Third International stands - Greenock, Govan, Kelvingrove and Motherwell as against Bridgeton and Shettleston - there was little difference in the percentage increase in their votes between 1918 and 1923 . Both benefited about equally. ${ }^{5}$

To give some examples. On the south-western periphery of Glasgow, in the shipbuilding community of Govan, the Marxist socialist Neil McLean won the seat in 1918 and increased his share of the vote in 1922. McLean, a member of pro-Third International wing of the Independent Labour Party (ILP), had previously been Scottish secretary of the Socialist Labour Party. He had opposed the war from a Marxist rather than pacifist position, was closely identified with the 1919 General Strike (chairing some of the meetings) and a leader of the Hands Off Russia campaign in 1919 and 1920. The constituency itself a strong tradition of working-class activism, demonstrated in the 1915 rent strikes, and possessed close links between the shipyard workforce and the local ward organisation (articulated through Govan Trades Council). In the 1918 election the temper of at least the younger members of shipyard workforce was strongly and explicitly socialist. Both Unionist and Liberal candidates were denied a hearing at public meetings, and, as cited earlier, there were vocal calls for revolutionary change along Russian lines.

In Kelvingrove across the river to the north, a partly middle-class constituency also contained the shipbuilding and engineering community of Anderston. Here an independent Labour candidate did badly in 1918 and in 1922 there was no challenge. In the 1922 by-election the Communist Aitken

${ }^{5}$ F.W.S. Craig, British Parliamentary Election Statistics, 1918-1945 (London, 1977), pp. 573-634. Additional information from the Call, Forward, and Govan Press. Maclean's votes in the Gorbals have not been included because it is not possible to make a direct comparison. In 1918 he was adopted as Labour candidate against Barnes, Coalition Labour, and gained $34 \%$ of the vote. In 1922, standing as Independent Communist, he gained $13 \%$ of the vote against the official Labour candidate with $54 \%$. Nonetheless this result does tend to reinforce the point about continued radicalisation being most marked in the areas of heavy industry rather than inner city areas of Glasgow like the Gorbals. 


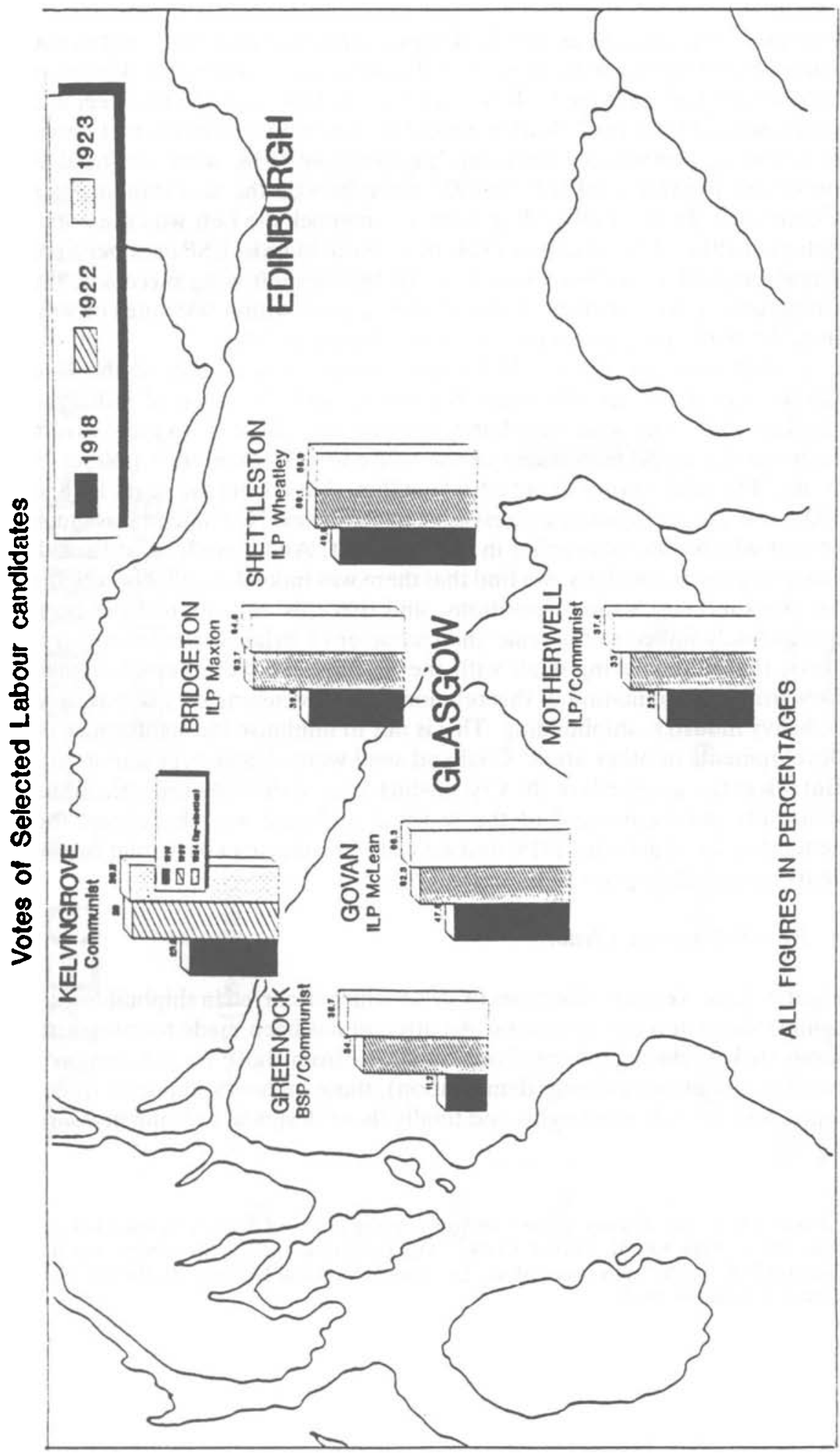


Ferguson was selected as official Labour candidate and came within 800 votes of winning the seat. In 1923, still fighting as a Communist, Ferguson increased his percentage to $40 \%$ with over 11,000 votes. In the steel and coal town of Motherwell Walton Newbold also received the official Labour nomination, and sharply increased his vote from 1918, when he stood as pro-Third International ILP, to 1922 when he won the seat standing as a Communist. In the shipbuilding town of Greenock the Left won the nomination in 1918, 1922, 1923 and 1924. In 1918 the Marxist BSP member Fred Shaw received a relatively poor vote. In 1922 his left-wing successor, the Communist Party member Arthur Geddes, came within 800 votes of winning the seat and again increased his percentage in $1923 .^{6}$

If, therefore, we reverse McLean's arbitrary redefinition of the Red Clyde, and if we actually study the timing and character of industrial conflict, then somewhat new horizons open up. There is no great divide between the workplace unrest of the war and the community politics of peace. The peak period of industrial conflict, that during the years 1918 to 1920 , was not sectional or conservative in character. Nor indeed was much of that which occurred earlier in the war itself. And if we look at the full range of electoral activity, we find that there was indeed significant support for revolutionary socialist positions, and that this appears to have been quite closely linked to the scale and character of strike action in industry. Next, therefore, having dealt with the legends, we will attempt to take forward our examination of this relationship by focussing on just one area of heavy industry, shipbuilding. This is not to minimise the significance of developments in other areas. Coal and steel were clearly very important. But it was the shipyards of the Clyde which played the initiating role in the politically most advanced of the wartime and post-war challenges, the general strike of January 1919, and we will concentrate in particular on the years immediately prior to it.

\section{How red was the Clyde?}

Figures 3 and 4 explore the types of strike which occurred in shipbuilding as against those in other industries. An attempt has been made to categorise these strikes: distinguishing those on wages from those on the sectional context of wage bargaining (demarcation), those on hours, those on tradeunion and shop steward rights and finally those designed to bring pressure

6 James Klugmann, History of the Communist Party of Great Britain, Volume I (London, 1973), Appendix II; Patrick Clark, "The Greenock Labour Movement and the General Strike 1926" (BA dissertation, Economic and Social History, Strathclyde University, December 1986). 


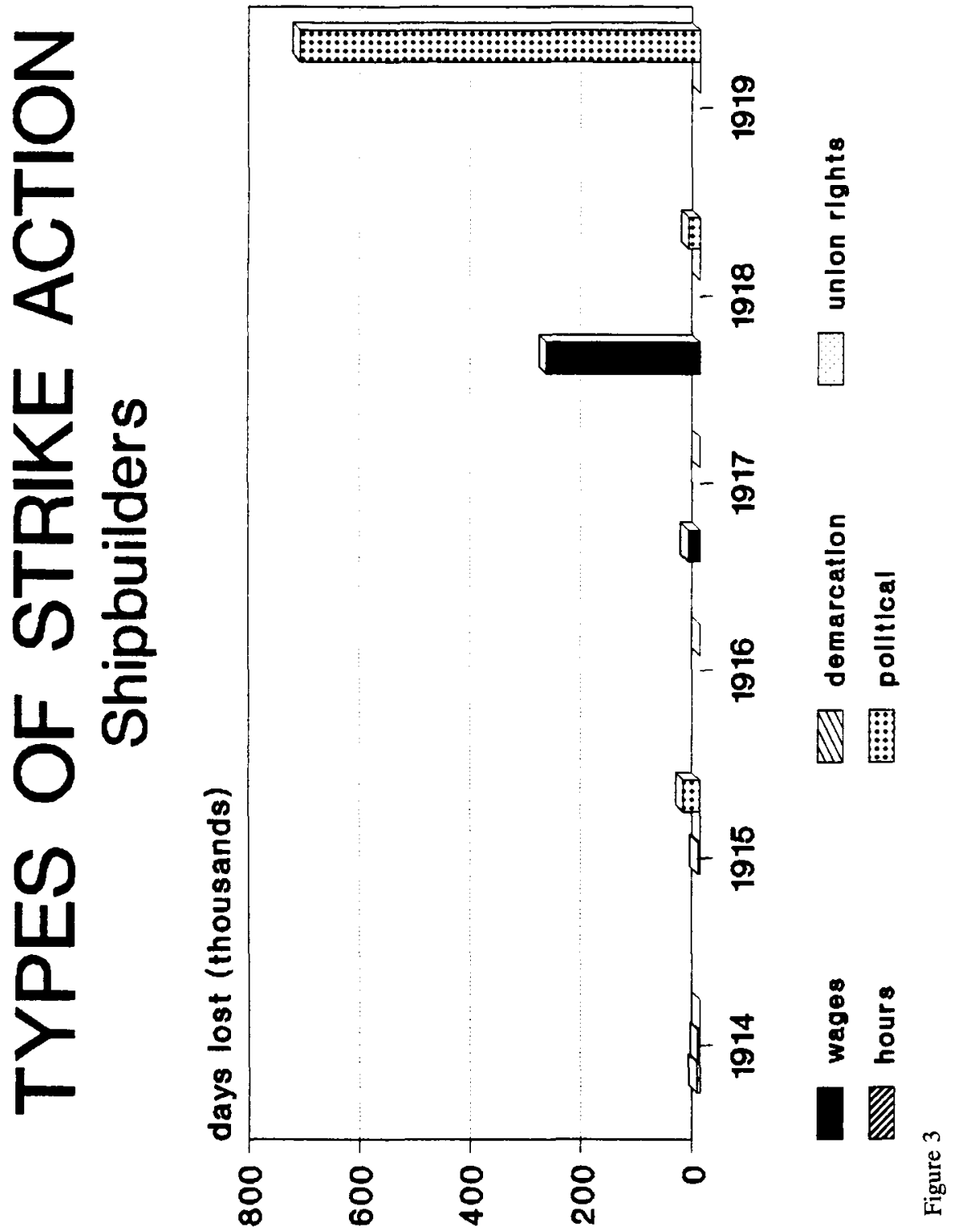



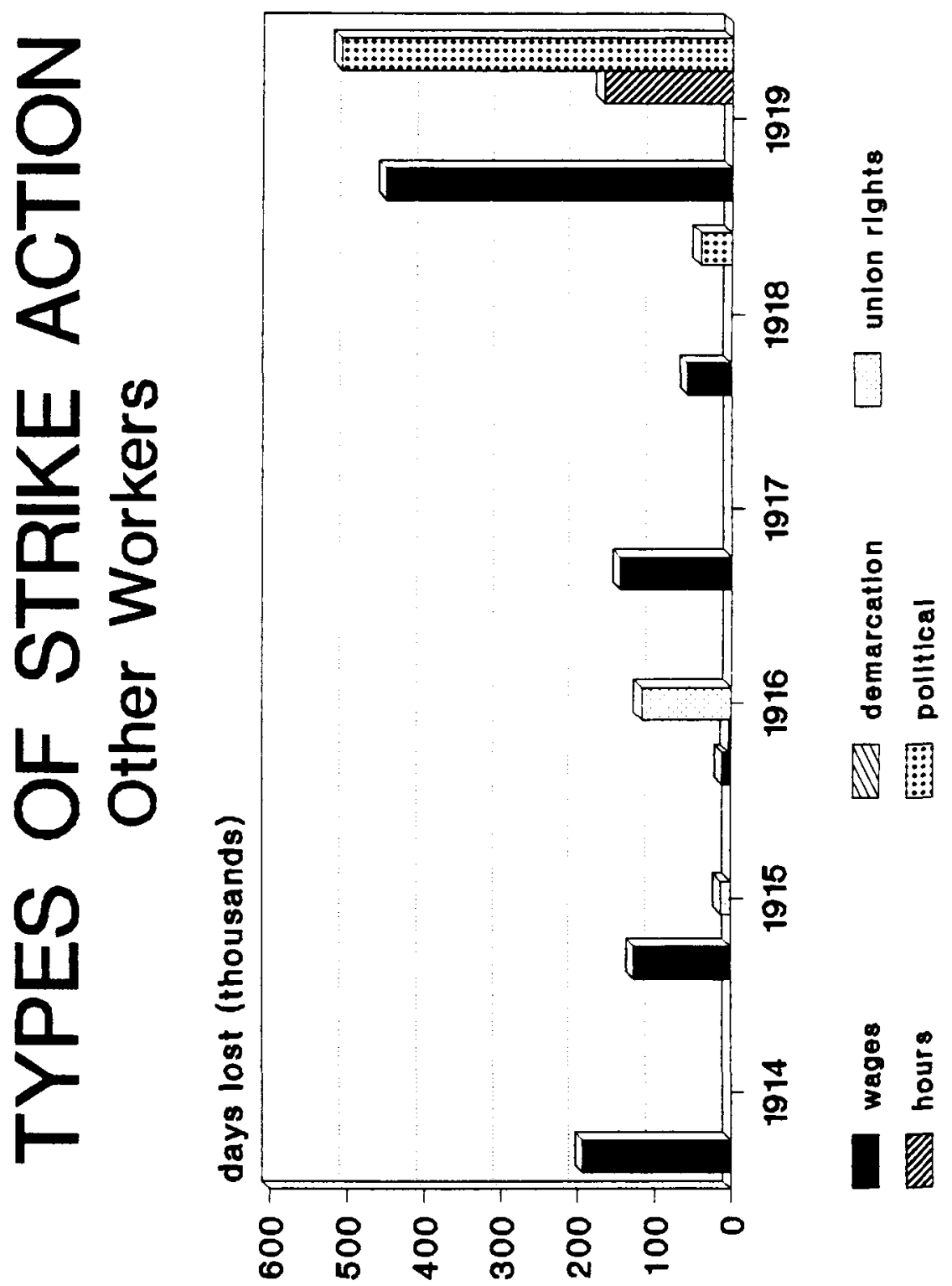

离 
to bear on government itself. ${ }^{7}$ Although this categorisation involves a degree of arbitrariness, it does provide some interesting initial pointers.

Looking at the overall sequence, the first major phase of strike action was on pay and initiated early in 1915 by engineering workers in munitions. It was followed by other unofficial strikes on pay, and it was this initiating role, rather than its actual size, which made the 1915 munitions strike so significant for contemporaries. Later in 1915 and into 1916 the emphasis shifts sharply as government agencies and employers sought to stamp out this unofficial action - not trade unionism itself - by curbing the ability of workers to organise independently in the workplace. Key issues here concerned the use of leaving certificates as instruments of managerial control and the rights of shop stewards. It is at this point, at the end of 1915 and into 1916 , that the issue of workplace bargaining rights seems to have become generalised across all sectors of employment. Strikes for union recognition and the closed shop erupt among previously unorganised or weakly organised workers outside heavy industry and engineering, and 1916 is notable for the degree to which the great bulk of days lost were not on wages but on trade-union and workplace rights. In 1917 and 1918 the emphasis shifts back to the use of this workplace bargaining power on a much broader front to secure wage increases which kept pace with inflation. Finally, at the end of the war another and still more significant phase of generalisation occurs. Where previously the issue of workplace power had been posed defensively - in terms of protecting shop stewards' rights - the demand was now for conditions, specifically shorter hours, which would perpetuate the favourable wartime labour market balance into the period of peace.

In reviewing these strikes it should be remembered that all stoppages in war-related industries were illegal. They were subject to fierce attack in the press, and portrayed as direct sabotage of the war effort. Penalties ranged from formal prosecution to the more informal removal of classified status and subsequent military conscription. Taking strike action usually meant defying official trade-union leaderships and rejecting the formidable apparatus of government-sponsored arbitration and conciliation. Yet, despite this, large numbers of workers were won to make direct use of the bargaining power that now lay in their grasp. This should remind us that the ideologies and sectional cultures that underlay the apparent quiescence of Clydeside's workers were not necessarily cast in stone. Even before the war sudden explosions of activism had occurred. The 1911 strike at the Amer-

\footnotetext{
${ }^{7}$ An estimate of 30,000 has been made for shipbuilding workers on strike on 17 November 1915 based on the Official History of the Ministry of Munitions Volume IV (part ii), p. 105; and 50,000 for the May Days of 1918 and 1919 based on estimates of 100,000 attendance in Forward and Glasgow Herald distributed half and half between shipbuilding and other industries.
} 
ican-owned, anti-union Singer plant in Clydebank was one example, and, interestingly, one where many of the activists were women. ${ }^{8}$

It is, as mentioned earlier, the working hypothesis of this article that Clydeside's industrial relations were significantly different from those in the industrial heartlands of England. Clydeside employers had little experience of managing through collective bargaining, and instead relied far more on autocratic power of undermanagers, foremen and chargehands and the ultimate sanction of dismissal. The characteristically cyclical nature of heavy industry made it possible to utilise trade downturns to enforce punitive action at the individual level - even if trade upturns made it necessary to buy cooperation by informal, workplace wage bargains. Correspondingly, workers relied far more on their direct, sectional bargaining power in the workplace itself.

This manipulative, coercive and sectionalised style of control was, therefore, particularly vulnerable to the coming of wartime full-employment. The consequences are seen quite dramatically in shipbuilding when we look behind the statistics to the documentary record. The apparently low level of recorded strike action on wages during the first year of the war is simply because managements conceded informal deals in face of unofficial workshop action. In July 1915 the Clyde Shipbuilders Association, the employers' organisation, was trying to get offending affiliates to reverse unofficial local wage concessions, and in September was lamenting the "continuous efforts to secure irregular increases in earnings and rates". ${ }^{9}$ The upsurge of strike action on trade-union rights came when workers believed that managements, with government backing, were seeking statutory means of limiting of this new workplace strength. The significance of the dispute over leaving certificates was that this seemed a direct method of reinstituting the coercive force of dismissal. At this point, in the autumn of 1915, government officials realised how volatile attitudes were. It was not just a matter of one particular grievance. The official History of the Ministry of Munitions cites the report by Isaac Mitchell: "the trouble had originated at Fairfields [in Govan, over unfair dismissals], but the men were full of other grievances [. . . ] an untoward incident might precipitate a stoppage at any moment, such as the decision given by the sheriff authorising the evictions of families because they were resisting the rise in rents". ${ }^{10}$ It was in this context that Govan Trades Council was able to go over the heads of the official trade-union movement and threaten a general strike across Clyde-

${ }^{8}$ The strike at Singers has recently been more fully reconstructed by a team of research workers under the auspicies of the Scottish Labour History Society. Charles Collins et al., The Strike at Singers (Clydebank Public Libraries, Clydebank, 1989).

9 Strathclyde Regional Council Archives Clyde Shipbuilders Association TD 241/1/15, 13 July and 28 September [hereafter, CSA].

${ }^{10}$ Official History of the Ministry of Munitions, Volume IV, pp. 50-55. 
side with sufficient credibility for the government to back down. It also saw the government acting very quickly to freeze rents when faced with the strike on 17 November which, again according to the History of the Ministry of Munitions, involved workers in "six great works and shipyards". The shipyards named, Barclay Curle, Fairfield, Harland and Wolff, Alexander Stephens and D. and W. Henderson, employed over 30,000 workers.

This eruption of direct action was followed very quickly by a period of apparent quiet. The government had conceded on rents, and leaving certificates were largely abandoned as instruments of control. In 1916 the shipyards played little part in the conflict between the Clyde Workers' Committee and the government. None of the yards struck work over the deportation of the CWC leaders. Yet it would not be correct to suggest that this lull in militancy was the result of some sort of ideological consensus - let alone one involving government officials. The real situation was far more ambiguous. Strikes were avoided not just by halting any real pressure for dilution but by systematic, and officially-countenanced, concessions on the pay front. A memorandum from the Ministry of Labour early in 1918 noted the prevalence of these illegal local arrangements and cited evidence to the Committee on Production that "the names of firms were torn off the pay sheets before the sheets were handed out". The memorandum continued: "The Ministry of Labour believes that there is something radically wrong with the employers on the Clyde as well as the men [...] the whole atmosphere of the Clyde denotes a moral rot, and such an atmosphere cannot ordinarily arise when relationships between employers and men are honorable even though they are not harmonious. There is a tendency to conceal facts on both sides." "Lynden Macassey, as head of the Admiralty's Shipyard Labour Department may have hoped that a soft approach on wages would open the way for dilution. He reported that when he took over at the beginning of 1917 the level of localised lightening strikes had "reached the figure of 50 to 60 per week", and by the end of the year he took credit both for radically reducing this number and for ensuring that the shipyards did not come out at the same time as the engineers in England in May $1917 .{ }^{12}$ But, if he had any hopes about progress with dilution, these were soon dispelled. The yard employers had no wish to face fresh disruption and, because of the cost-plus basis of their wartime contracts, no financial incentive for pursuing dilution. By October 1917 Macassey was accusing employers of obstruction and proposing that legal action be taken to penalise them. Somewhat ingenuously, he picked on the biggest firm on the Clyde: "the leading action for such opposition", he wrote, "seemed to

11 PRO ADM 116/1608; Ministry of Labour, 12 February 1918.

12 PRO ADM 116/1602; memorandum from Lynden Macassey, 24 April 1918. 
come from Mr Henry Lithgow and the various firms he controlled". ${ }^{13}$ Those in charge at the Admiralty, who themselves had the closest of business links with shipping and shipbuilding, would have none of it. ${ }^{14}$

Autumn 1917 brought a full scale crisis on the issue of shipbuilding production. Losses at sea far exceeded the output from the yards. Imported food supplies were dwindling, and politicians began to look for scapegoats among those in the Admiralty who supervised shipyard production. The Admiralty's response was to blame the shortage of skilled labour and demand that 20,000 men with shipbuilding skills be released from the colours. It also sought to deflect some responsibility elsewhere by blaming the Ministry of Munitions for inadequate deliveries of steel. The Ministry of Labour and the Ministry of Munitions both reacted angrily by accusing the Admiralty of not making any attempt to cut labour costs ("an industry notorious for the least possible dilution") and for conniving at local pay deals which destabilised wage agreements throughout the rest of industry: "individual advances which have forced up the district rate". ${ }^{15}$

Ultimately it was the attempt to defuse these mounting wage pressures outside shipbuilding which led to the massive shipyard strikes of January 1918. The Ministry of Munitions agreed to a scheme for a $12 \frac{1}{1} 2 \%$ bonuses to be paid, after arbitration, to certain categories of skilled time workers whose real wages had fallen sharply in face of inflation. The shipyard trades immediately claimed this for themselves on terms which signified a massive rank-and-file revolt against the official rates previously arbitrated between their union leaders and the government. By December 1917 the Ministry of Munitions was monitoring attitudes on the Clyde with increasing anxiety.

As in autumn 1915, we get the impression from government reports of a diffuse unrest in the yards which combined material and political grievances. There was acute official concern over the psychological impact of the Lansdowne letter which finally revealed divisions within the political establishment over the issue of a negotiated peace. This, it was reported, had played into the hands of those unofficial leaders who opposed the war itself. "The early months of 1918", commented the Ministry of Munitions Clyde Labour Report for the week ending 15 December, "may reveal industrial action with a view to the achievement of political ends in the termination of war conditions." 16 War weariness was now compounded by a serious housing shortage and problems with food supplies. By 28 December the Minis-

13 PRO ADM 116/1609; memorandum from Macassey of 17 October 1917 enclosed in a confidential report on Macassey from Lord Pirrie to Eric Geddes as First Lord of the Admiralty.

${ }^{14}$ Eric Geddes, the First Lord, had shipping interests, Lord Pirrie, the Controller of Shipping, ran Harland and Wolff, James Lithgow, Henry's brother, was appointed Controller for Shipbuilding early in 1918. Macassey resigned.

15 PRO ADM 116/1608; 12 February 1918.

16 PRO MUN 2/28 Labour Reports, week ending 15 December 1917, p. 14. 
try of Munitions was reporting that a serious rank-and-file revolt on pay was in the making and was "revealed in the tendency on the part of the rank and file to repudiate trade union officials and constitutional channels". ${ }^{17}$ The unrest in the yards was also interlocking with resistance to the draconian new "comb out" provisions of the new conscription bill. The riotous meeting between the Clydeside shop stewards and conscription minister Aukland Geddes in January 1918 had clear parallels with the barracking of Lloyd George two years before. The meeting demanded a negotiated peace and expressed support for the initiatives taken by the Soviet government in Russia. According to the Ministry of Munitions' chief investigator, those attending were fully accredited shop stewards and representatives of workplace opinion. ${ }^{18}$ By then the Clydeside yards were out on strike and for that month contributed up to three quarters of all days lost in the country. The Minister of Munitions put the blame squarely on "the pacifist and revolutionary section of the men". ${ }^{19}$ The Ministry of Labour warned "if the trouble on the Clyde continues, it may have grave results of which the country must be made aware" ${ }^{20}$ By the end of January the Ministry of Munitions reported a widening of resistance and a "solidification of opposition to the Man Power Bill - at least among members of the ASE". By 2 February the situation was described as "grave" and a "stoppage of work on a large scale extremely probable". ${ }^{21}$ The Ministry of Labour highlighted Beardmores as a possible flashpoint. This massive firm, which spanned both heavy munitions and shipbuilding, was noted for its highly autocratic management. "From the evidence before the Chief Industrial Commissioners' department it is clear that bad relations exist. The dangerous fact in this not uncommon position is that Gallacher, McManus and one or two more of the most powerful extremists are employed at Beardmores in various works. That they have the will and the power to exploit any trouble [. . . ] can be shown by the serious consequences which were threatened by the alleged victimisation of four women workers at East Helen Street, where a national stoppage was suggested." The Ministry urged the Prime Minister to intervene directly. Otherwise Beardmores might provide the spark "which lights a big fire". 22

This quite highly charged situation in late December 1917 and January 1918 occurred at a time when public meetings several thousand strong were being held by both the ILP and the BSP on peace demands. By late

${ }^{17}$ PRO MUN 2/28, week ending 28 December 1917; 2/14, week ending 13 February 1918.

${ }^{18}$ PRO MUN 2/14, week ending 2 February.

${ }^{19}$ PRO ADM 116/1608; memorandum from Churchill, 8 February 1918.

20 PRO ADM 116/1608; Ministry of Labour, 12 February 1918.

21 PRO MUN 2/14, weeks ending 23 January 1918 and 2 February 1918.

22 PRO ADM 116/1608; Ministry of Labour, 12 February 1918. 
December the first real news was coming through about the November revolution. Reports in both the ILP's Forward and in the BSP's Call show national ILP leaders such as Ramsay MacDonald having to pay at least lipservice to Lenin's peace policy when speaking to Glasgow audiences, and strong pressures emerging from the ILP rank and file in the west of Scotland for a harder line from the Labour Party nationally. ${ }^{23}$ Oral testimony from those then working in the shipyards recalls this as a period of intense discussion, especially among apprentices, and crowded meetings taking place night after night.$^{24}$ As early as mid-January 1918 John Wheatley, main Clydeside leader of the anti-Marxist trend in the ILP, had started a series of articles in Forward designed to combat the growing identity with the Russian Revolution and Marxist socialism. ${ }^{25}$

In all this there is, therefore, little evidence of the shipyards acting as any kind of basis for a progressivist and constitutional consensus involving government officials and trade-union leaders. On the contrary, what we appear to be seeing is one further stage in a process of political radicalisation. Previously in autumn 1915 the battle to defend workplace bargaining rights had become closely associated with workplace intervention in the politics of the community. On that occasion, however, the demands of the shop stewards and the rent strikers had been phrased "patriotically". High rents were penalising families with men in the army and harming the war effort. ${ }^{26}$ Landlords were "huns" exploiting the wartime pressure on housing. By January 1918, the demand for increased wages was coupled with a call for peace which explicitly challenged the nature of the war and the class character of the government.

It took a sophisticated and concerted campaign of official intervention to turn the tide - first and foremost by conceding all along the line on wages. By mid-February Ministry of Munitions officers were able to report that the "serial" concession of the $12^{1} / 2 \%$ war bonus to progressively wider grades of workers had started to relieve the situation. On the propaganda front, the detailed activities of the government and management-sponsored War Aims Committee in each workshop were reported to have "snowed under" resistance to the Man Power Bill by the passage of resolutions supporting the government position. By 13 February the situation was "distinctly easier" and by 20 February there were "no serious disputes" and the ASE district committee had dropped the question of the Man Power Bill. ${ }^{27}$ In this

${ }^{23}$ Forward, 12 January 1918; Call, 17 December 1917 and 20 January 1918.

${ }^{24}$ Finlay Hart, apprentice at John Brown's, Clydebank; taperecording by author in STUC archive; William Gallacher, Revolt on the Clyde (London, 1979), p. 181.

25 Forward, 26 January 1918; comment Call, 31 January 1918.

${ }^{26}$ Gerry Rubin, War, Law and Labour; the Munitions Act, State Regulation and the Union 1915-1921 (Oxford, 1987), pp. 64-107, examines the arguments of shipyard workers attending tribunals in summer and autumn 1915. 
crisis the government agencies seem to have seen their best tactic to be the traditional one of buying off confrontation and then seeking to rally loyalist and patriotic opinion in the workplace.

This time, however, the stabilisation also seems to have been accompanied by far more detailed victimisation than that which occurred during spring 1916. Known socialists in the shipyards were discharged for war service. ${ }^{28}$ Repeated raids were made on the Socialist Labour Party and BSP offices and printing presses. Leaders of the large Russian refugee community were arrested in February - and in March John Maclean also. ${ }^{29}$ So, although stability was restored, it was in the context of far more overt repression. Unlike workers in Sheffield and Manchester, no attempt was made to secure strike action against the conscription of skilled workers. Yet the government was clearly very concerned about the growth of socialist influence. These months appear to have seen a major stengthening of the core of pro-socialist opinion that was most tangibly revealed by the preparations for the first May Day strike. By February Glasgow Trades Council and the other trade-union organisations represented on the May Day Committee had been won to support a stoppage on May Day. ${ }^{30}$ Over the following two months effective, detailed work in the workshops secured a relatively massive response. Few estimates put the number attending below 90,000 and despite a heavy police presence no attempt was eventually made to stop the march. Resolutions were passed at all nineteen platforms in favour of a cessation of hostilities, the release of Maclean and support for the Russian Revolution. In early autumn 1918 there was yet another surge of unofficial wage militancy in the yards. The BSP paper, Call commented: "distrust of 'leaders' is rapidly developing into repudiation and when the men on strike, at a mass meeting last week, turned down emphatically the recommendations of their local officials to return to work pending a settlement they were demonstrating that they, the rank and file, were the masters". ${ }^{31}$ Even this, however, does not prepare us for the next upsurge in early January 1919.

The strike in January 1919 for a 40-hour week was not just incomparably bigger than anything that had gone before. It was also far more radical in both its tactics and demands. Again we have been somewhat decoyed from the real issues by the revisionist historians who have concentrated on who precisely was responsible for the outbreak of violence in George Square on 31 January 1919. We still lack a full account of where the strike was most firmly based, which grades and types of workers led it, what the tactics of

27 PRO MUN 2/14, weeks ending 23 January 1918, 13 February and 20 February 1918.

28 Call, 7 March 1918 reports on conscription of militants in the yards.

${ }^{29}$ Forward for January, February and March 1918.

${ }^{30}$ Call, 21 February 1918.

31 Glasgow Herald, 2 May 1918; Forward, 4 May 1918; Call, 26 September 1918. 
the employers were - and, perhaps most interesting of all, a comparative study of the parallel strike in Belfast, also based principally in the shipyards.

Nonetheless, the records of the Clyde Shipbuilders Association do shed a certain amount of new light. These records were not used by either Hinton or McLean and only selectively by Reid whose reconstruction of industrial relations in the shipyards unaccountably ends before the 40-hours strike. The records show us, first of all, what the employers saw as new and particularly dangerous about the strike. This was that it was entirely unofficial and political rather than industrial. Its leaders repudiated the nationally negotiated 47-hour working week recently agreed between the Confederated Unions and the Shipbuilding and Engineering employers. ${ }^{32}$ Worse than this, the unofficial rank-and-file leadership of shop stewards, led by the socialists within the Clyde Workers' Committee, had been able to win key elements of the regional trade-union movement to support their position. This included Glasgow Trades Council, the Scottish Trades Union Congress and the Glasgow District Committee of the engineering union. The secretary of the engineers district committee, Harry Hopkins, was an enthusiastic supporter and was the man who, when secretary of Govan Trades Council in 1915, had organised the threatened general strike across Clydeside. The objectives in 1919 were openly political. They were to secure a radical reduction of hours to forty in order, quite explicitly, to stop the re-emergence of an unemployed reserve and maintain the bargaining strength of labour against capital. A direct aim was to ensure that discharged soldiers were found jobs in industry. ${ }^{33}$

It was for this reason that the tactics of the employers were initially to avoid any direct involvement. "The strike was against the trade union officers and the strikers' fellow workers rather than against the Employers, and therefore the latter did not wish to appear in the matter". ${ }^{34}$ Their expectation seems to have been that, with little or no official support, the strike would crumble very quickly. The estimate of the CSA was that the strike had the active and enthusiastic support of only about $25 \%$ of the workforce in the shipyards. This represented the 14,000 workers on the Upper Clyde who came out on strike immediately. The assessment of the North West Engineering Employers was about the same. On this basis the employers were not initially in favour of any military intervention. The Scottish Secretary of State, Munro, told the Cabinet on 28 January that he had "talked that morning with certain leading Glasgow citizens who suggested what was most needed was unofficial propaganda". ${ }^{35}$

32 This account is mainly taken from Strathclyde Regional Council Archieves TD 241/1/1 CSA minute book [hereafter, RD].

${ }^{33}$ Forward for January and February 1919.

34 Strathclyde RO TD 241/1/18, 30 January 1919.

${ }^{35}$ PRO CAB 23/9, 28 January 1919. 
This position changed dramatically within four days. What transformed the situation, at least in the minds of the employers and the Ministry of Munitions investigators, was the strikers' use of mass pickets. By 30 January there were 40,000 on strike in shipyards and engineering works on the Upper Clyde, and the strike had spread to the shipyards on Lower Clyde and the Forth. The electricity supply workers had struck work in Glasgow, and according to Board of Trade records, 36,000 miners had come out on sympathy strike in the Lanarkshire and Stirlingshire coalfields as had 10,000 iron moulders. ${ }^{36}$ Most other trades had also ceased work in Glasgow and surrounding areas. In assessing the role of these mass pickets two factors, both hitherto largely neglected, would seem to be important.

The first is the participation of discharged servicemen. The British Socialist Party appears to have been involved in organising servicemen since early the previous year. In February 1918 the Glasgow Federation of Discharged Soldiers and Seamen was claiming 3,000 members and campaigning on issues of housing and rents. In August 1918 it was holding simultaneous demonstrations with those organised for the release of Maclean and providing protection from police attack. ${ }^{37}$ Now in January 1919 support from demobilised soldiers was seen by the employers as one key element in the spread of the strike. At the joint emergency meeting of the CSA and the NW Engineering Employers on 31 January a major item of discussion was the wisdom of issuing a "manifesto to the effect that two months from this date should there be a number of demobilised soldiers still out of employment, the Employers would either by reduced hours or other means give them employment" ${ }^{38}$ Oral history testimony makes it clear that large numbers of demobilised soldiers were among the 60,000 demonstrators assembled in George Square on 31 January and that they had a prominent part in the fighting which erupted after the first police baton charge. Shinwell implies that Scots regiments had been particularly to the fore in the demobilisation mutinies which occurred in December $1918 .{ }^{39}$

The second feature of the mass pickets is the degree to which they were in fact genuinely mass, involving women and young people and almost to have a carnival aspect to them, marching with drums and other musical instruments. In Clydebank apprentices seem to have been particularly to the fore. ${ }^{40}$ So although the employers and Ministry of Munitions officials saw

${ }^{36}$ PRO CAB 23/9, 30 January; Board of Trade Labour Gazette, February and March 1919.

${ }^{37}$ Call 21 February 1918 (letter from W. Caven), and 8 August 1918.

${ }^{38}$ Strathclyde RO TD 241/1/18, 31 January 1919.

${ }^{39}$ Taperecorded interview by the author with Tommy Graham and Jimmy Ferguson (STUC archive); E. Shinwell, I've Lived Through It All (London, 1973) pp. 39-45.

${ }_{40}^{40}$ Taperecorded interviews by the author with Bob Saunders, Jimmy Ferguson and Finlay Hart (STUC archive). 
the spread of the strike to be the result of coercion and force ("it is unsafe for anyone to remain at work"), the very rapid geographical extension of the strike clearly indicates a much wider political support for its aims. ${ }^{41}$

It was this aspect which seems to have induced the employers to revise their tactics and call for military intervention. There were two quite unprecedented emergency conferences convened jointly by the two major employers associations, one on 31 January and the other on 14 February. Each was attended by over a hundred employers. On 31 January the executives of the two associations reported on the steps they had taken or proposed to take. These give some indication of their priorities. Just prior to the meeting the Lord Provost of Glasgow had been interviewed by executive members and reprimanded for receiving a deputation from the strikers. $\mathrm{He}$ had also been urged to take immediate action against the "unruly mob" then assembling outside the City Chambers. The editors of the Scottish press were to be called in and told to effect a "judicious cutting down of statements concerning the unofficial strike and eliminating from reports the names of the strike leaders". Those official trade-union leaders not implicated in the strike had been interviewed and told to issue statements indicating that unless the strike was called off all agreements entered into since 1914 would be scrapped. The Lord Provost had also been told to request the government to sanction the establishment of a Civic Guard: "quite a number of loyal workmen and employers would join the Guard with a view to opposing the strikers".

Clearly, therefore, the government's decision to despatch 5,000 more troops and to order a tank regiment to take up dispositions that would enable the area to be sealed off was not, as the revisionists have claimed, simply a laughable and ill-informed overreaction. It was a response to urgent a change in local assessments and marked an attempt to compensate for what seems to have been an earlier underestimate of the strike's potential. It would appear that the BSP and Socialist Labour Party leaders on Clydeside were also taken aback by the speed of events. They had been working towards some form of general strike action on hours over the previous months and had been attempting to win support throughout industry in the west of Scotland. But, as John Maclean noted in the Call on 30 January, they had intended that the lead would be taken by the numerically biggest contingent of Clydeside workers, the miners, and also, it would seem, wanted more preparatory work done in other parts of Britain. In an earlier article "Now's the Day, Now's the Hour" published the previous week, four days before the strike began, Maclean acknowledged that politically they should be calling for a general strike to halt British intervention in Soviet Russia. But this was not feasible. The workers were

${ }^{41}$ PRO MUN 1/17 Labour report for 31 January 1919. 
"not generally of our way of thinking". However, there was very considerable support for action on the issue of hours in face of overproduction and unemployment, and this should be the strategic priority.

Hence, what we are dealing with in 1919 would seem to be one further moment in a sequence of industrial eruptions, as in autumn 1915 and autumn 1917, but one in which there was a considerably stronger political element and which interacted with forces outside industry, among the ex-servicemen and the unemployed, to produce a more far-reaching political transformation. The employers' initial estimate of 14,000 active supporters was probably not inaccurate. But it has to be matched against the government estimate of 60,000 in and around George Square five days later and the spontaneous decision of 36,000 miners to come out as well. ${ }^{42}$ Moreover, the effect of military intervention and the arrest of the strike's leadership was initially at least to strengthen the strike, and the decision to return to work ten days later does not seem to have brought a collapse of morale. The second emergency conference of employers on 14 February was very wary of future events. It rejected calls from the Beardmore's management for a purge of shop stewards and was greatly concerned by reports that the Belfast employers were negotiating for a "less than 47 hour week". ${ }^{43}$ This was a "most unfortunate" development and a deputation was sent off to urge them to stand firm. The minute books of the CSA for the following month record an intransigent attitude by workers at least two major shipyards - ignoring instructions by officials of the Boilermakers Society and stating that they were acting under the instructions of the shop stewards only. ${ }^{44}$ In April the CSA impotently expressed its annoyance that the Clyde District Committee of the Boilermakers had unilaterally announced May Day as a holiday without any attempt at negotiation. ${ }^{45}$ The 100,000 attending again passed resolutions of support for the Russian Revolution, demands for British withdrawal from Russia and for a socialist revolution in Britain.

So we return to a modification of our original question: how red had the Clyde become by 1919 ? In the shipyard and some steel and mining areas it would appear that by 1919-1920 support for revolutionary socialist positions had gained a firm foothold. This seems to be substantiated by the electoral record, and also by internal developments within these industries. James Lithgow, the major shipyard employer on the Clyde, claimed in 1919 that Bolshevism had gained a definite base among the workers in his yards on the Lower Clyde, and called for mass sackings along the whole river. ${ }^{46}$

${ }^{12}$ MUN 5/18, 1 February 1919.

${ }^{43}$ TD 241/1/18, 14 February 1919.

4eardmores and Hendersons: Strathclyde RO TD 241/1/18, 13 and 25 March 1919.

${ }^{45}$ TD 241/18, 24 April 1919.

46 Alan McKinlay, "The Depression, Job Control and 'The Workers' Foreman': Ship- 
Alan Campbell's research on the Lanarkshire coalminers points to these years as the key turning point in the victory of those calling for affiliation to RILU. ${ }^{47}$ The socialist minority among younger workers and apprentices seems to have emerged significantly stronger. The experience of military intervention, the continuing international advance of socialist revolution in Europe, and the clear determination of employers to re-impose pre-1914 conditions all appear to have undermined the credibility of both the old pre-war official leaderships and the vacillating reformists on the right-wing of the ILP.

To a lesser extent it is probably legitimate to claim that parallel developments took place generally within the working population on Clydeside. The mass involvement in the 1919 strike, its slogans of unity between employed and unemployed and its dramatic conclusion would seem to have played some part in the transformation of attitudes between 1918 and 1920 . One key piece of evidence here is the position of the Independent Labour Party. In 1919 this was still the main organised element, in terms of a mass local membership, within the Labour Party in Scotland. Until 1920 it was conference policy of the Scottish ILP, in sharp distinction to the British ILP, to seek affiliation to the Third International. The conferences of 1919 and 1920 took this position in defiance of the British leadership and the Scottish right-wing gathered round Wheatley. The strongest base for the Left in the ILP was in the shipyard areas of Govan and Partick, and these were also the areas that had the largest and most stable membership. Already in December 1918 the powerful Govan Central branch of the ILP was calling for affiliation to the west of Scotland Soviet established by the CWC and the BSP in the period immediately preceding the January general strike. However, the ability of the ILP Left to win votes at Scottish level through 1919 and 1920 clearly shows a geographically much wider spread of support. Alan McKinlay's recent research on the Scottish ILP has underlined the degree to which there remained a high degree of political fluidity between Marxist and non-Marxist positions - until the early 1920 s. $^{48}$

If, therefore, we are to sum up our conclusions so far, we might say that although Clydeside did not become Britain's Petrograd, its experience was nonetheless somewhat exceptional. It may not have been the only exception within Britain, and for quite long periods of the war there was less open

building Riveters 1919-1935", Scottish Economic and Social History, IX (1989).

${ }^{47}$ Alan Campbell, "From Independent Collier to Militant Miner", Scottish Labour History Society Journal, XXIX (1989), pp. 8-23.

48 Alan McKinlay, " 'Doubtful Wisdom and Uncertain Promise': Strategy, Ideology and Organisation 1918-1922", in Richard Morris and Alan McKinlay (eds), The Independent Labour Party in Scotland (Manchester, 1990). I am grateful to Dr McKinlay for the Govan central branch reference (Glasgow ILP Minute Book, 17 January 1919, Mitchell Library Glasgow). 
support for resistance to the state war machine than elsewhere. But in 1919 Clydeside did witness the most significant upsurge of socialist-led industrial action of the whole period, and it is this which poses the question with which we will be concerned for the remainder of this article.

Why did it happen on Clydeside - rather than elsewhere? Clydeside's concentration of heavy industry was not totally dissimilar from those in England. On Tyneside and in the northwest and the midlands there were massive munitions industries, and indeed the central triangle of Manchester, Leeds and Birmingham contained far more workers in heavy industry than there were in Scotland. Moreover, why, anyway, should it be workers in heavy industry, boilermakers, engineers and miners, who took the lead? On Clydeside these contingents within the workforce had been traditionally characterised, far more than in England, by sharp ethnic segmentation and pronounced sectionalism.

A parallel question has recently been posed by Igor Klyamkin. ${ }^{49} \mathrm{He}$ uses the development of working-class mobilisation in Petrograd to interrogate the concept of the Labour Aristocracy as used by Lenin. In Petrograd it appears to have been the most skilled grades of workers in the biggest factories who provided the firmest base for socialist politics in 1917, and did so even though, in terms of pay, they enjoyed considerable differentials over the workforce in general. Yet when explaining the reformism of the Labour Movement in Western Europe Lenin had attributed such attitudes precisely to the privileged positions of the upper strata of workers. Klyamkin argues that the key element in Lenin's specification of the Labour Aristocracy is not the differential of pay itself but how it was maintained, its political significance, and the wider framework of social privileges to which skilled workers had access. The difference between skilled workers in Petrograd and those in Manchester or Berlin was the degree to which the skilled workforce had been incorporated within the constitutional structures of the existing system. They saw their ability to negotiate effectively as dependent on this privileged legal position. In Petrograd, on the other hand, the position of indigenous Russian capital was economically far too marginal to afford such concessions and it remained wedded to an autocracy which excluded, or sought to exclude, workers from significant political rights. If skilled workers in Petrograd won higher wages, it was by virtue of their organisation at the point of production.

It is the argument here that a parallel uneveness, even if on a smaller and less dramatic scale, also existed within the British isles. Klyamkin's points about the absence of a material basis for the political integration of the skilled worker would seem to be directly relevant to the experience of

49 Igor Klyamkin, "The October Revolution and the Issue of the Subject in History", Social Sciences, USSR Academy of Sciences, 4 (1988), pp. 93-111. 
Clydeside. We will therefore shift to a somewhat wider historical focus and examine the politico-economic background to Clydeside's labour relations.

\section{Scottish capital and labour relations}

Joseph Melling's seminal article on employer associations on Clydeside was published almost ten years ago as was $\mathbf{R}$. $\mathbf{H}$. Campbell's study of the rise and fall of Scottish heavy industry. ${ }^{50}$ Yet it is only recently that a beginning has been made at integrating either text into our understanding of the regional uneveness of labour relations in Britain. We have known for a long time that the level of trade-union membership in Scotland was up to 20\% lower than that in England in the 1890s and largely restricted to heavy industry. ${ }^{51}$ Emigration was also far higher and without the constant and disproportionately larger inflow of Irish labour Scotland's population would have stopped growing in the late nineteenth century rather than the $1920 \mathrm{~s}^{52}$ It is, however, the recent reworking of the pre-1914 trade-union unemployment benefit records which has revealed Scotland's starkly different experience in the field of employment. ${ }^{53}$ Against the conventional wisdom, the highest rates of unemployment in the half century to 1914 were found to be not in London and the south but in Scotland and the northern regions where cyclical trade fluctuations had a far more protracted effect. Partly this resulted from the high concentration of capital goods production in these areas. But it was not just this.

The importance of Campbell's work is to show that compared to similar production elsewhere Scottish heavy industry was undercapitalised, less productive and itself more cyclical. Quite different business strategies were at work - as one might expect in a country industrialising alongside a much more powerful and advanced neighbour which largely determined the tempo of the business cycle and dominated its own national market. So, although Scottish employers often made good profits and were not bereft of capital, they placed their emphasis on cutting costs and prices. Their typical

so R.H. Campbell, The Rise and Fall of Scottish Industry 1707-1939 (Edinburgh, 1980); J. Melling, "Scottish Industrialists and the Changing Character of Class Relations in the Clyde Region", in T. Dickson (ed.), Capital and Class (Edinburgh, 1982), pp. 61-142; J. Foster and C. Woolfson, The Politics of the UCS Work-In: Class Alliances and the Right to Work (London, 1986), especially chapter 3 "The Roots of Sectionalism and Solidarity". All these texts examine the issue of regionality and the uneven development of capital in Scotland.

51 Sidney and Beatrice Webb, The History of Trade Unionism (London, 1920), pp. 428-440.

${ }_{52}$ D.F. MacDonald, Scotland's Shifting Population (Glasgow, 1937), pp. 14, 77.

53 Humphrey Southall, "The Origins of the Depressed Areas: Unemployment, Growth and Regional Economic Structure in Britain Before 1914", Economic History Review, XLI (1988), pp. 236-258. 
response was to minimise capital overheads and to rely on the one major "national" advantage remaining to Scottish capital: its much more direct control over the local institutions of civil society, the kirk, the school and parish relief. This provided one major lever for the maintenance of cheap and malleable labour. The other was structural unemployment. Throughout the nineteenth century Scottish employers remained intensely concerned about the existence of adequate labour reserves. New investment always had to be matched to local labour markets, and lower wages were seen as the vital component for successful competition. Even in the 1920s, it remained a settled conviction of Scotland's industrial leaders that any resumption of investment and economic growth would depend on how far a substantial wage differential could be established against England. Scottish employers consequently required both more labour for a given volume of production, and, at the same time, to be able to keep it cheaper.

Melling's 1982 article explores the employment strategies which made this possible. Central was a bitter determination to exclude trade-union organisation. From the middle years of the nineteenth century Scottish practice diverged increasingly from the norm of collective bargaining being adopted in England. Hamish Fraser dates the crucial change to the cotton spinners' trial of $1837 .{ }^{54}$ But, whatever the turning point, the rebuilding of Scottish capital formation after the catastrophic collapse of the Scottish cotton industry in the 1840 s was on the basis of eliminating trade-union organisation even where it had previously existed. This was so for the surviving remnant of the cotton industry, for iron and steel, for most of the west of Scotland coal industry and particularly for the new iron and steel shipbuilding industry. Lock-outs to exclude any form of trade-union presence took place routinely. Many firms remained intransigently anti-union up to the First World War, and it was only after two generations of very bitter struggle that trade-union recognition was finally granted in shipbuilding itself.

This industry typifies the difference in employer practice between Scotland and England. In both countries employment was highly cyclical, and in both the typical employer response was to retain only a core of permanent skilled workers, platers, shipwrights, chargehand riveters. The rest, the bulk of the riveters, the fitting-out trades and the labouring and semi-skilled workers, would be hired as trade expanded. But the way in which this was done was very different. In England the permanent core of skilled workers would be trade unionists who had enjoyed recognised rights to collective bargaining since the mid-century. The permanence of their employment and the privileges that went with it meant that their trade unionism tended

${ }^{54}$ Hamish Fraser, Conflict and Class: Scottish Workers, 1700-1838 (Edinburgh, 1988), p. 170. 
to be sectional and exclusive - even to the extent of opposing unionisation among the non-skilled workers in the $1880 \mathrm{~s}$. But these skilled workers were by definition trade unionists with an independence from management which gave them an autonomy within the yard and, no less important, within the wider social and political community. In Scotland the links between the permanent workers and their employers was far more archaic. The core workers were management loyalists and at least during the formative stages of the industry were anti-union. Management loyalism was maintained both by direct incentives, such as tied housing, and often by the cultural bonding of Masonic membership. It was these men who were responsible for recruiting labour when required. As in Belfast, the other shipbuilding centre with which the Clyde had very close business links, this power was exercised in a way that sustained strong ethnic segmentation within the workforce and permitted the regular elimination of militants.

For forty years up to 1900 this type of employment practice made it possible to keep wages up to $10 \%$ below the English level. The battle to achieve union recognition and wage parity with English workers was a very recent memory at the time of the First World War. The crucial struggles had largely coincided with, and not preceded, the unionisation of the unskilled from the 1890s, and success had depended on the organised strength of particular skill groups at the point of production. Each recession would see managements once more on the offensive. Each revival in trade would see workers reinstating their claims, and the organisation which defended the rights of each shipyard trade had to be continuously reasserted. So, although shipyard trade unionism on the Clyde was highly sectional, it was sectional in a way that was rather different to that in England. It did not rest on the national position of the union and the recognised standing of the skilled trade unionist in the workplace. It depended on the direct readiness of workers to defend their gains, and was far more immediately about the balance of workplace power between capital and labour.

It is important not to exaggerate or romanticise the difference. Naturally workgroup organisation was also important in the south. In Scotland, as skilled grades become unionised, so sectarian and ethnic divisions became internalised within trade-union structures in much the same way as in Belfast - though probably with somewhat less intensity. Trade-union membership overall also remained significantly lower even when established in shipbuilding and mining. Yet even with these qualifications there was a sharp difference in content of labour movement ideologies in the two countries, a difference in perspectives particularly sharply expressed in the boilermarkers' union. This conflict came to a head in the 1890s. The main basis of boilermakers' membership had long been in the English districts where collective bargaining was the norm. As the Clyde District membership grew in size, so did disagreements over tactics. The English-dominated 
executive under Robert Knight was committed to the principle of industrial arbitration through national procedures. The Scottish membership wanted to be able to exploit the labour market as and when possible by direct resort to strike action. The rank-and-file revolt which eventually toppled the old executive originated on Clydeside and focussed on the refusal of strike pay for striking Scottish members. ${ }^{55}$

This conflict of perspectives within the boilermakers' union was also taken on to the wider political stage. It had been pressure from Robert Knight and the union's executive which in 1894 had successfully managed to exclude trades councils from representation at the Trades Union Congress. The reasons for removing trade council representation explicitly referred to the socialist orientation of many of these bodies and no doubt also included their identification with new unionism and their support for independent labour representation. The response of the Scottish trades councils, particularly those in which shipyard trades had a major place, was to set about the establishment of a Scottish Trades Union Congress. From its inauguration in 1897 the STUC was committed to independent labour representation and the socialisation of the means of production. The trades councils which took the lead, Greenock, Govan, Falkirk, and Motherwell, had in many cases come into existence during the growth of New Unionism in the early 1890s, and self-consciously referred to themselves as the "iron trades councils". Govan prided itself on the fact that it admitted unskilled, labourer delegates from some of the New Unions excluded by Glasgow trades council. ${ }^{56}$

Correspondingly, a quite distinct pattern of labour politics can be seen crystallising in the west of Scotland by the 1900 s. The emphasis was far more on independent labour representation as distinct from the election of labour and trade-union candidates within the ranks of the two bourgeois parties. Given the anti-union stance of the employers who dominated the bourgeois parties, there was in fact little alternative. A Conservative party which exploited Orangeism and a Liberal Party funded by the steadfastly anti-union Coats (thread) family, left little scope for alliances with organised labour. Nor was there much scope for cooperation in local government. Scottish employers wanted far too a unilateral grip on local affairs, at least in their fiefdoms in the industrial hinterland of the Clyde Valley, to permit more than a pale reflection of Lib-Lab politics and Fabian progressivism in Scotland. In the shipyard burghs and coal and steel townships the

${ }^{55}$ J. Mortimer, History of the Boilermakers' Society (London, 1973); Calum Campbell, "The Making of a Clydeside Working Class: Shipbuilding and Working Class Organisation in Govan", Our History, 78 (July 1986). The latter uses the 1881 census schedules to examine occupational ethnic segmentation in shipbuilding.

${ }^{56}$ Angela Tuckett, The Scottish Trade Union Congress: the First 80 Years, 1897-1977 (Edinburgh, 1986), pp. 26-41. I am also grateful to Angela Tuckett for transcripts of the STUC minute books. 
parochial dominance of local business left little room for genuinely autonomous civic institutions. Unlike England there was no electoral pact with the Liberals negotiated in 1903 (implemented in the 1905 general election) and the Marxist Social Democratic Federation remained on the Scottish Workers Representation Committee. Inevitably the lack of Liberal support, and the small size of the Scottish trade-union base, resulted in far less Labour representation in either local government or in the 1906 parliament. But it also meant that Labour's electoral politics had a sharper class flavour and posed societal change much more in class terms. Intervention in local politics was directly seen as an attempt to break the stranglehold - in education, poor relief, housing, heath and hygiene-exercised both formally and informally by the proxies of local business, and workplace struggle remained the immediate backcloth. This provided the soil in which Marxist organizations, like the BSP and the SLP, could grow, and perhaps more important, it also meant that the ILP itself had a quite different character to that in England. There was no sharp dividing line in Scotland between labour and Marxist politics, and even before the First World War close local links existed with the BSP and its propagandists such as Maclean and Gallacher. ${ }^{57}$

So a number of differences should now be clear. Unlike England, collective bargaining was a recent and fragile growth, and many large employers remained wedded to anti-union policies. Moreover, these specifically Scottish features were rooted in the material weakness of Scottish business. Its leaders could not afford to treat trade unionists with the same easy familiarity as their English counterparts, and organised labour, as against often loyalist individual workers, remained in an oppositional position within the structures of local government and civil society. In industry it was indeed true, as Reid notes, that trade-union officials were more than usually responsive to their members. But this was because they had little alternative. Scottish shipyard workers remained intensely sensitive to anything that might change the context of their workplace bargaining. Conversely, despite the ultimate recognition of collective bargaining, and the strenuous efforts by management to use union officials as surrogate loyalists, the authority of the official movement remained structurally weak.

This would seem why the coming of wartime full employment, and the removal of the basic management weapon of dismissal, had such an adverse

57 John Holford, Reshaping Labour: Organisation, Work and Politics in Edinburgh in the Great War and After (London, 1988), pp. 63-99 provides evidence which suggests that the pattern in Edinburgh, where much of the employment was non-industrial or in English managed railway companies, may have been closer to that south of the border; David Englander, Landlord and Tenant in Urban Britain 1838-1918 (Oxford, 1983), especially chapter 10 , provides an important review of local tenant politics for the west of Scotland. 
effect in the west of Scotland. A quite disproportionate amount of government energy appears to have been spent during the opening years of the war on stabilising its labour relations, and one constant complaint of the government officials responsible was the 'backward' attitudes of management. Figure 5 shows the proportion of Scottish disputes referred to either the pre-war Arbitration and Conciliation Committee or to the new wartime Committee on Production - of which quite a significant number were in areas where union recognition had been entirely denied before the war. ${ }^{58}$ By 1915 almost $20 \%$ of all UK references were being generated by the $6 \%$ of the labour force in the west of Scotland. The fact that there were not still more was only because, as we have seen, it was the practice of the shipyard employers, faced with highly profitable contracts and the need to keep and attract skilled labour, to concede informally and without publicity through the early stages of the war.

The work of the Glasgow munitions tribunal was, as Gerry Rubin has recently shown, particularly difficult and fraught. The approach of the workers was very much framed within the assumptions of class antagonism. Every attempt would be made to use mass attendances to frighten and intimidate the tribunal chairmen - and with no little success. Ultimately the government had to sack two of the chairmen to encourage the others and in 1916 the Munitions of War Act was amended to permit a more enforceable sentencing structure. Even so the law seems to have remained highly elastic and to have responded to the degree defendants were collectively organised. ${ }^{59}$

We may conclude, therefore, that there were somewhat special factors at work within the labour force on the Clyde. The bargaining position of labour was seen far more to depend on its own organisational strength than on any privileged position either within the workplace or outside. Before the war management depended on an uneasy and instable mixture of semi-casual employment, dismissal and ethnic segmentation. In wartime the balance changed. The rapid expansion of the workforce eroded both the coercive power of management and, in both Glasgow and Belfast it seems, some elements of ethnic segmentation. Eruptions of strike action occurred whenever it seemed that management was seeking to use legal curbs to redress the balance. This was the case in 1915 . In late 1917 and early 1918 the issue was more the wider constraints imposed by the government's arbitration procedure. On both occasions a resolution was only achieved by the carefully orchestrated use of material concessions to redivide workshop opinion and contain the influence of the socialist Left. Each time, however,

58 These figures are calculated from the monthly returns in the Board of Trade Labour Gazette.

${ }^{59}$ Rubin, War, Law and Labour, p. 62. 


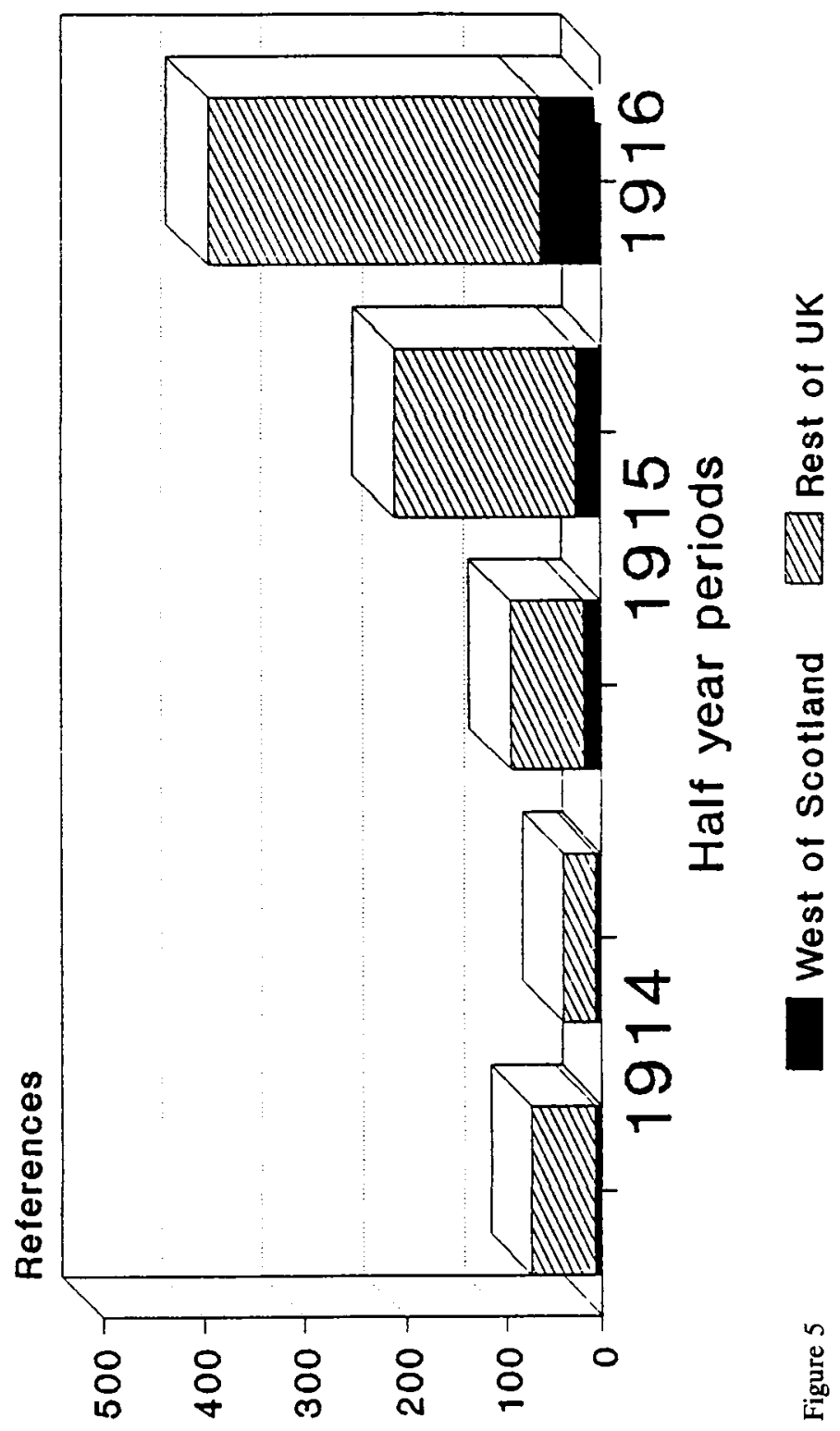


the critical mass of socialist opinion within the yards seems to have increased. In December 1918 and January 1919, when it became clear that the employers intended to return the balance to its pre-war basis by the restoration of an unemployed reserve, it was possible for the Left to win support for very advanced demands with remarkable speed. The Left was then able to consolidate its position still further, at least in the areas of heavy industry, as the state responded in a way that clearly exposed it as an instrument of capital. There is an interesting contrast here with Belfast. There the British State was at that moment too weak - both physically and in terms of its ability to sustain any wider social base - to intervene directly. The employers' tactic was to temporise while building up loyalist sectarian forces outside the workplace. The resolution of the crisis came a few months later when paramilitaries were used to clear the yards of opposition in the course of an anti-Catholic pogrom..$^{60}$ Only at one moment, with the call for the creation of a Civic Guard, do Clydeside employers appear to have contemplated a similar type of solution.

\section{Socialist politics and uneven development}

This article has sought to demonstrate that the Red Clyde was a real phenomenon. It was geographically limited and relatively quickly contained. Mass unemployment returned - with an especially savage culling of the shipyard workforce from 65,000 to 23,000 by $1921 .^{61}$ Employers were able to eliminate militants and restore the authority of full-time trade-union officials. Nonetheless, a significant section of the younger members of the workforce had been won, at least temporarily, for a socialist position, and many retained this commitment for the rest of their lives.

By international standards this achievement bears some respect. It should be remembered that most of the directly revolutionary industrial action in central Europe, mass strikes and the establishment of workers councils, took place after military defeat when state institutions had either collapsed or were in terminal crisis. Where state institutions remained relatively stable, as in France or Italy, major strikes waves certainly did occur. But in terms of both size and political scope that on Clydeside in January 1919 stands comparison with any of them. In France the post-war emphasis was also on the question of hours and the maintenance of labour's wartime bargaining power. But neither in Paris nor in any of the industrial regions was there quite the same combination of action between different

${ }^{60}$ Paul Bew, Peter Gibbon and Henry Patterson, The State in Northern Ireland 1921-72 (Manchester, 1980), chapter 2.

${ }^{61}$ P. Payne, "Scottish Heavy Industry", in Richard Saville (ed.), Economic Development of Modern Scotland (Edingburgh, 1986), pp. 79-113. 
industries, employed and unemployed, ex-soldiers, women and local communities. ${ }^{62}$

We have endeavoured to demonstrate that the reason for the apparent exceptionalism of Clydeside is to be found in the politico-economic marginality of west of Scotland's heavy industry. The very fast growth of Clydeside as an industrial centre from the middle years of the nineteenth century depended in particular on lower wages and a far more total control over labour. This aspect of Scottish industrial practice had heavy costs once war conditions had transformed the balance of class power. As Klyamkin has argued for Petrograd, and Diane Koenker for Moscow, the lack of economic and social space for the maturing of a labour aristocrat political culture in the full sense of civic institutions which locally gave a corporate role to labour - seems to have been a major factor in the victory of socialist ideology among skilled workers. ${ }^{63}$ In the British isles it might indeed be advanced as a more general thesis that the areas in which there was most wartime radicalisation were outside what has been called the "core" areas of nineteenth century industrialisation and were where the industrial base for labour aristocratic politics had previously been weakest: in London, Ireland, Clydeside and possibly South Wales. ${ }^{64}$ But this still leaves the question of political intervention. In what circumstances, and at what historical moments, did these transformations of attitude occur?

Two points seem to emerge from the experience on Clydeside. One is the importance of the interaction between a particular experience of class politics in the community and the politics of the workplace. The special character of the ILP, as the major mediator in this process, has already been explored by Melling and Mackinlay. ${ }^{65}$ The other point is the importance of large-scale industry. Belligerent anti-union managements existed across Clydeside. Wages and conditions were generally worse outside large-scale

62 G. Ribeill, Les Cheminots en Guerre, $1914-1920$ (Paris, 1988); J.-L. Robert, La Scission Syndicale de 1921 (Paris, 1980); Yves Cohen, "Peugeot et la région de Montbéliard, 1919-1922”, paper presented to the Colloquium on Revolutionary Movements, Graz, 1989.

${ }^{63}$ Diane Koenker, Moscow Workers and the 1917 Revolution (Princeton, 1981), and "Workers and Society in Revolutionary Moscow: Collaboration and Polarisation", paper presented to the Colloquium on Revolutionary Movements, Graz, 1989.

${ }_{64}$ Ron Martin, "The Political Economy of the North South Divide", in Jim Lewis (ed.), The North South Divide (London, 1989), pp. 20-60 for the definition of the industrial core as against the industrial periphery. An initial and now somewhat dated review of regional variations in the breakdown of the labour aristocracy can be found in J. Foster, "British Imperialism and the Labour Aristocracy", in J. Skelley (ed.), The General Strike of 1926 (London, 1976), pp. 1-57; an examination of the specific character of this formation in London is made in J. Foster, "How Victorian London preserved its Slums", in International Journal of Urban and Regional Research, III (1979), pp. 93-114.

65 Joseph Melling, "Work, Culture and Politics on 'Red Clydeside': the ILP during the First World War", in McKinlay and Morris (eds), The Independent Labour Party in Scotland. 


\section{BSP Branch Activity} Govan
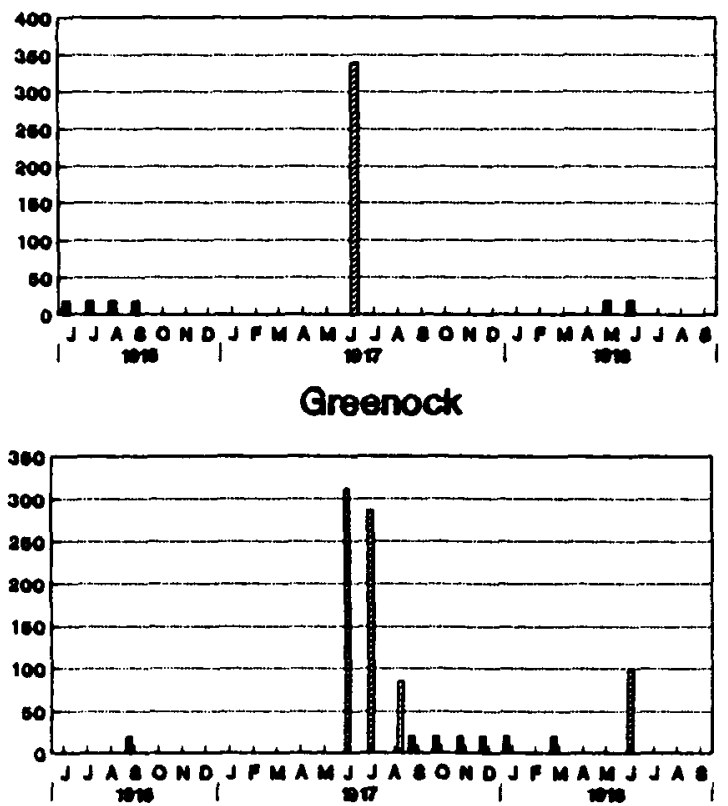

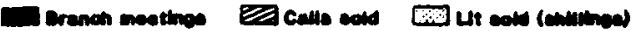

Paisley
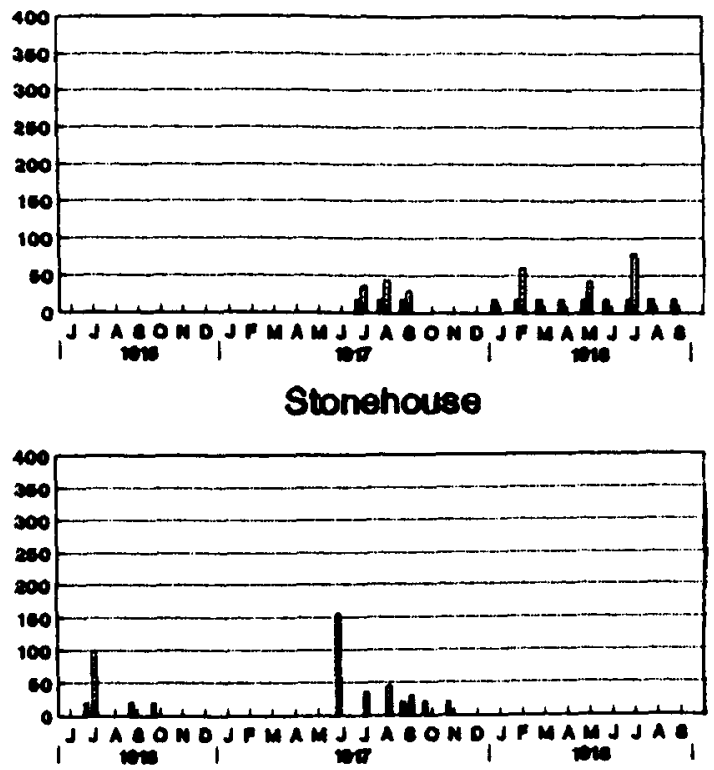

Figure 6 
industry, and the biggest concentrations of slum housing were in the central areas of Glasgow rather than the periphery. Yet it was heavy industry areas which responded.

This is shown relatively sharply in Figure 6. This records the activity of a number of British Socialist Party branches after 1916 by reconstructing from the branch reports in its weekly paper, The Call, the regularity of meetings and, perhaps more reliably in terms of comparison, the recorded levels of literature sales (in shillings) and Call sales. ${ }^{66}$ Probably the most consistent branch in terms of activity was Paisley. Paisley was William Gallacher's home town. Through most of the war he maintained an active role in its trades council and was the mainstay of its branch. But Paisley was dominated by relatively small-scale firms in machine tools, textiles and subcontract engineering, and the Left never achieved a dominant position either within the Labour movement or the population as a whole. The shipbuilding town of Greenock, on the other hand, had a branch which had clearly achieved a significant base in industry by summer 1918 when 125 members enrolled in its economic class and when Marxist arguments were, according to the branch report, being carried into every workshop on the Lower Clyde ${ }^{67}$ Again in Govan, where the level of branch activity was very intermittent (and the ILP was dominant), Call sales, when recorded, were much higher than those in Paisley. The same also applies to the coalmining community of Stonehouse in Lanarkshire.

This would seem to indicate that the missing ingredient in Britain was not so much an effective political party - either the BSP after its re-establishment in 1916 or, at least in Scotland, the ILP. It was more the politicoeconomic soil in which socialist forces could grow. On Clydeside by 19171918 the BSP's local branches and industrial cadre force were working closely with the Left in the ILP and the Socialist Labour Party and a dense network of political organisation had been created across the region. The core leadership of the Left in Scotland was also, despite imprisonment, conscription and high levels of police harrassment, relatively effective and mature. Yet it was only in areas of large-scale industry that socialist politics became a significant force. Of key importance here would seem to be the ability of workers in large workplaces to generalise issues and accumulate experience: the consolidation over time of a critical mass of people with the necessary knowledge for wider class action. It was here that the lessons of each struggle could be assimilated and passed on, and critically - because of the character of Clydeside labour relations and community politics - these lessons were socialist rather than social democratic.

${ }^{66}$ The branch reports are drawn from a search of the Call from February 1916 to August 1919.

${ }^{67}$ For the economic class in Greenock, 15 November 1917; for Paisley, James Brown, "From Radicalism to Socialism: Paisley Engineers 1880-1920"; Our History, 71 (1980). 